\title{
沿岸長周期波の発生と伝播特性に関する研究 GENERATION AND PROPAGATION OF COASTAL LONG WAVES
}

\author{
青 木 伸一 \\ Shin-ichi AOKI \\ 正会員 工博 豊橋技術科学大学 助教授 建設工学系（テ441-8580 豊橋市天伯町雲雀ケ丘 1-1)
}

\begin{abstract}
Characteristics of generation and propagation of coasatal long waves with periods of several minutes are discussed based on field data obtained at Akabane on the Enshu coast and at Are in Tsushima island. Differences in amplification of the long waves at the two locations are highlighted and discussed in relation with incident wave properties. Field data obtained by other researchers at different locations are used to compare the amplification characterstics. Wave heights of long waves at most locations are linearly proportional to the products of significant wave height and period. Generation of free long waves with large amplitude is indicated on gentle sandy beaches. Propagation of the free long waves in on-offshore and longshore directions are also discussed.
\end{abstract}

Key Words: long wave, wave amplification, wave propagation, bound wave, free wave

\section{1.まえがき}

沿岸で生じる周期数分程度の長周期波は，数秒〜 十数秒にエネルギーのピークをもつ通常の風波成分 に比べると波高は小さいものの，港湾における副振 動や係留船の長周期動摇を誘発したり 1),2),3), 外洋 に面した海岸や港周辺の漂砂現象に大きな影響を及 ぼすことが指摘されている4),5)。このような長周期 波は防波堤など従来の波浪制御構造物ではコント ロールすることが難しいばかりか, 構造物の設置に よって，かえって長周期波を増幅させたり，場合に よっては新たな長周期波を生み出したりすることも ありうるため，対策に苦慮している場合が多い。

このような長周期波の存在は観測によって古くか ら認識されおり6), 現地デー夕の整理や種々の理論 的なアプローチもなされてきたが，長周期波の増幅 や伝播の特性など，その実態にはまだ不明な点が多 い。ただし，近年，波高計などの観測装置の発達や コンピューターの性能向上によって時空間的に大量 のデー夕を取得・解析することが可能になってきて おり，様々な状況下での長周期波に焦点を絞った現 地観測により，その特性が次第に明らかになってき ている.これまでの長周期波に関する研究の流れゃ 位置づけについては，合田7)や関本8)が詳細なレビ ユーを行っている. 本研究は, 著者らが行った 2 地 点での現地観測結果を中心に，その他の研究者の観 測結果もまじえて，長周期波浪の増幅と伝播に関す る諸特性について考察したものである.

\section{2. 現地観測の概要}

著者らは, 渥美半島太平洋岸の直線的な砂浜海岸 に位置する赤羽根漁港沖（海底勾配0.01程度, 波高 計設置水深12〜14m）において，1996年以来継続し て台風期の波浪観測を行ってきた9),10),11). 図一1 は各年の波高計の設置位置を示したものである。ま た，2001年 2 月〜 3 月の期間，長崎県対馬の西海岸

（岩礁海岸）に位置する阿連漁港沖および港内にお いて冬期風浪の観測を行った。阿連漁港周辺の地形 と波高計（3 台）の設置位置を図一 2 に示す。沖側 の波高計の設置水深は約 $21 \mathrm{~m}$ である.

\section{3. 長周期波の増幅特性}

\section{（1）長周期波の分類と出現特性}

比較的波高の大きな時期の波浪デー夕（潮汐成分 は除く）をスペクトル解析すると, 通常は周期20〜 30秒付近にエネルギーの極小值が現れ，それより長 周期側で再びエネルギーが増大している場合が多 い.この長周期波成分のうち，周期 20 秒〜数分程度 U波は，一般に20秒以下の風波やうねりの波浪特性 との関連性が強く, 特にその卓越周期は波群の包絡 波の周期にほぼ対応している.一方, 数分程度以上 の長周期波は，短周期の波成分との関連性が低い場 合が多く, 気圧変動や風などの気象擾乱が原因で発 生していると考えられている。本研究では，一般的 ではないが, 便宜上, 前者を波群性長周期波, 後者 


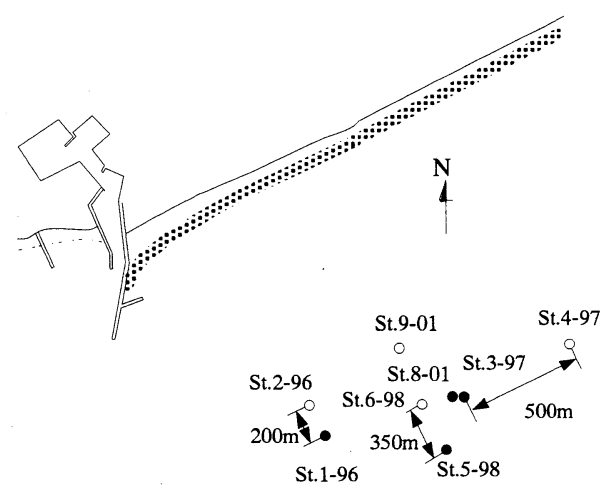

図一1 赤羽根漁港沖での波高計の配置

（各年とも 2 台の波高計を用いて同時観測. 一は超音波式 水位計, 水圧計および流速計を, ○は水圧計と流速計のみ を有する波高計. 前者については 2 時間おきに 40 分間, 後 者については連続観測. サンプリング周波数は $2 \mathrm{~Hz}$ )

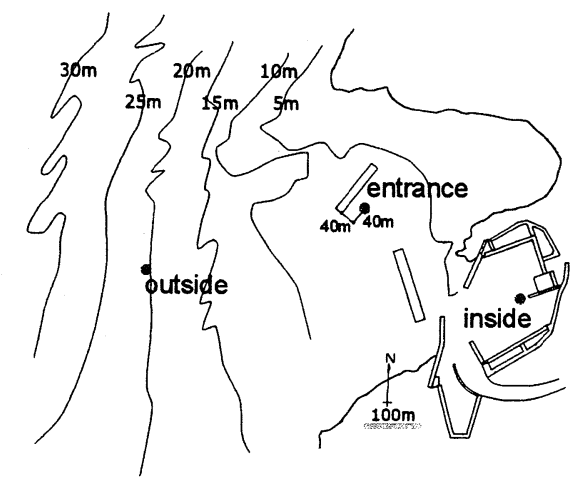

図-2 阿連漁港内外の波高計の配置

（図中の沖および港口部の波高計については超音波水位計， 水圧計および流速計を，港内の波高計は水圧計と流速計のみ を有する．沖および港内の波高計では連続データを，港口部 の波高計は 2 時間おきに 40 分間のデー夕を取得. サンプリ ング周波数はいずれも $2 \mathrm{~Hz}$.

を気象性長周期波と呼ぶことにする．長周期波に関 する研究の多くは前者の波群性長周期波を対象にし ているが，本研究ではさらに周期の長い気象性長周 期波まで含めて取扱うことにする。ただし，潮汐に よる数時間周期の変動までは含めない.

図ー3および図－4は，赤羽根および阿連（沖 側）における長周期波の時系列から求めたRMS值 （標準偏差）の経時変化を有義波高と有義波周期の 変化とともに示したものである．ただし長周期波成 分の分類については，そのスペクトル形状より，赤 羽根では30〜300秒を波群性長周期波，300秒以上の 波を気象性長周期波と定義した。一方阿連において は，風波の周期が短いことから，20〜200秒の波を 波群性長周期波，200秒以上の波を気象性長周期波 とした。これらの波の抽出は，いずれもフーリエ変 換による数值フィルターを用いて対象とする周期帯 の波の時系列を再構成することにより行っている.

図一３および図ー4より, 両地点とも, 波群性長

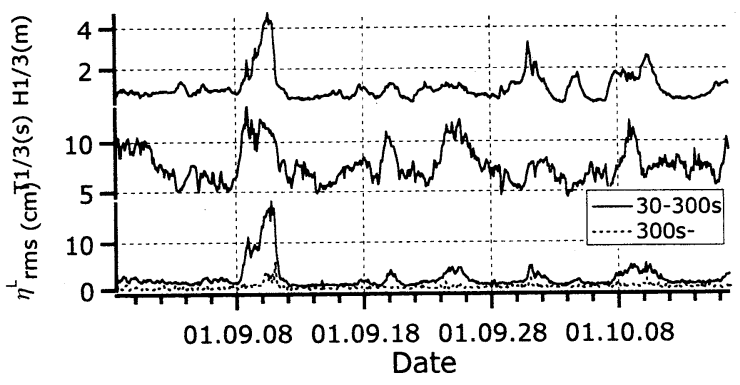

図一３赤羽根における長周期波の経時変化 (St.8-01での観測值)

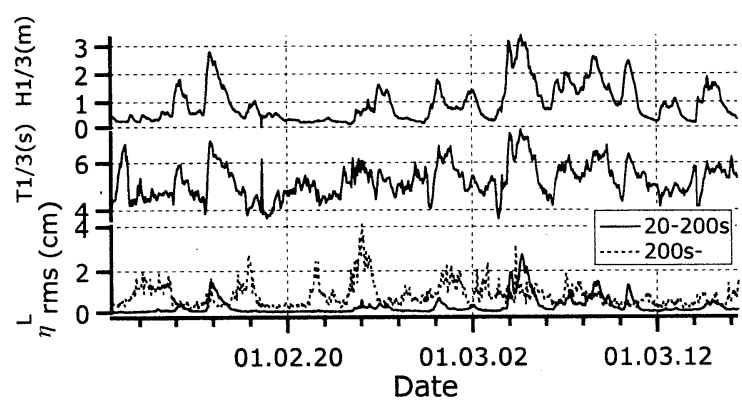

\section{図ー4 阿連における長周期波の経時変化 (沖側波高計の観測值)}

周期波は有義波高および有義波周期の増大とともに 増大する傾向がはっきり現れている．ただし，赤羽 根の方が全体的にエネルギーレベルが高い。一方気 象性長周期波については, 両地点とも大きさは同程 度であるが, 阿連では波群性長周期波が小さいた め, 気象性長周期波が相対的に大きくなっている. また, 特に阿連においては, 気象性長周期波は有義 波高や有義波周期と無関係に発生している場合も多 く見られる.

\section{（２）赤羽根と阿連での長周期波の増幅特性}

図一 5 および図一 6 は，それぞれ赤羽根および阿 連における 2 種類の長周期波のRMS值を有義波高と 有義波周期の積 $H_{1 / 3} T_{1 / 3}$ を横軸にとって示したもの である。ただし，図ー5では，波群性長周期波につ いては 5 年間の全てのデータセット（約 1200 個） を, 気象性長周期波については2001年の観測值のみ をプロットしている。これより, 赤羽根では波群性 長周期波のRMS值は， $H_{1 / 3} T_{1 / 3}$ にほぼ線形的に増加 すると見ることができ，その比例定数は $0.003[1 / \mathrm{s}]$ 程度である。また，気象性長周期波については，増 幅率が極めて小さいことがわかる。一方, 図-6の 阿連の観測値を見ると, 赤羽根に比べて増幅率が非 常に小さく, $H_{1 / 3} T_{1 / 3}$ との関係も 2 次関数的な変化 を示している.また, $H_{1 / 3} T_{1 / 3}$ の小さな範囲で, 大 きな気象性長周期波が現れている点が特徵的で, そ の值は荒天時の波群性長周期波よりも大きいものも 


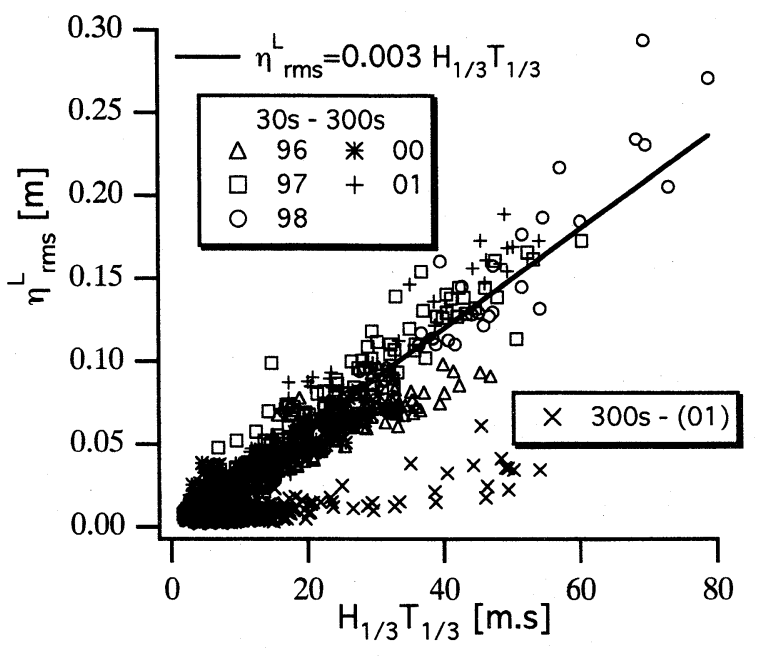

図－5 赤羽根における長周期波の増幅特性

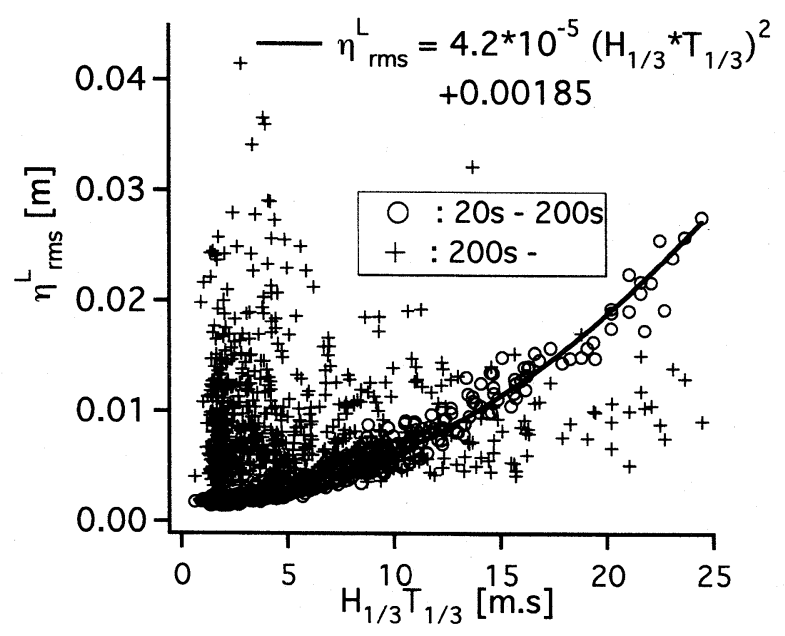

図ー6 阿連における長周期波の増幅特性

みられる. 以上のように, 赤羽根と阿連のように， 波浪条件や地形条件が異なる海岸での長周期波の増 幅特性は大きく異なることがわかった。

\section{（ 3 ）長周期拘束波の特性}

ここでは，波群性長周期波について若干理論的な 考察を行う.波群性長周期波には, 波群を構成する 短周期波の非線型干渉によって生じて波群とともに 進行する拘束波と, 波群の変形過程で生じる自由波 が存在する. 発生機構から明らかなように, 拘束波 は，ローカルな波浪特性のみによって決まることか ら，図一5および図一6のような関係を見る場合に は，拘束波の波高および周期への依存性をあらかじ め把握しておく必要がある. 拘束波の理論について は, Yoshida ${ }^{12)}$, Longuet-Higgins and Stewart ${ }^{13)}$, Ottesen-Hansen ら 14)等によって一方向進行波に関す る解が示されている。またSand ${ }^{15)}$ は進行方向の違い を考慮した解析解を示している.

Ottessen-Hansen らの一方向進行波の解を用いる と, 振幅 $(=a)$ が等しく, 周波数が $\omega$ （波数 $k ）$ と
$\omega+\Delta \omega （$ 波数 $k+\Delta k$ ）の 2 つの波の 2 次干渉による長 周期拘束波（周波数 $\Delta \omega$ で群速度 $c_{g}=\Delta \omega / \Delta k$ で進行す る波）の解は， $\Delta \omega / \omega か ゙$ 微小であるとすると，次式 で与えられる。

$$
\frac{\left|\eta^{L}\right|}{h}=\frac{n \beta^{2} / \alpha+\beta^{2} /(\cosh 2 \beta-1)}{n^{2}-\beta^{2} / \alpha} \frac{a^{2}}{h^{2}}
$$

ここに, $\left|\eta^{L}\right|$ は拘束波の振幅, $h$ は水深, $n$ は波速と 群速度の比であり, $\alpha=\omega^{2} h / g, \beta=k h$ とおいている。 さらに, 浅海波 $(k h<<1)$ の近似を行うと, 次式を 得る。

$$
\frac{\left|\eta^{L}\right|}{h}=\frac{3}{8 \pi^{2}} \frac{g T^{2}}{h} \frac{a^{2}}{h^{2}}
$$

（1）式と（2）式を比較して，（2）式の適用限 界をみたのが図ー7である。図は, 各式の右辺の $a^{2} / h$ の前の係数を $G^{*}$ とし,$\sqrt{g / h} T$ の関数としてプ ロットしたものであるが， $\sqrt{g / h} T>4$ の範囲では 両者はほぼ一致している。この限界は， $h=30 \mathrm{~m} て ゙$ $T>7 \mathrm{~s}, h=10 \mathrm{~m}$ で $T>4 \mathrm{~s}$ である. 成分波の振幅 $a$ の代わ りに波高 $H$ を用いて（2）式を変形すると

$$
\frac{\left|\eta^{L}\right|}{h} \sim \frac{g T^{2} H^{2}}{h^{3}}
$$

となり，上記条件を満たす浅海域では，拘束波の振 幅は波高と周期の積の 2 乗に比例することがわか る. 図一 6 の阿連の増幅傾向はこの拘束波の特性を よく表している．従来は，拘束波の波高と有義波高 との関係が論じられることが多かったが，有義波高 と有義波周期の積で整理した方が現地データがよく まとまるのは上記の性質のためであろう.

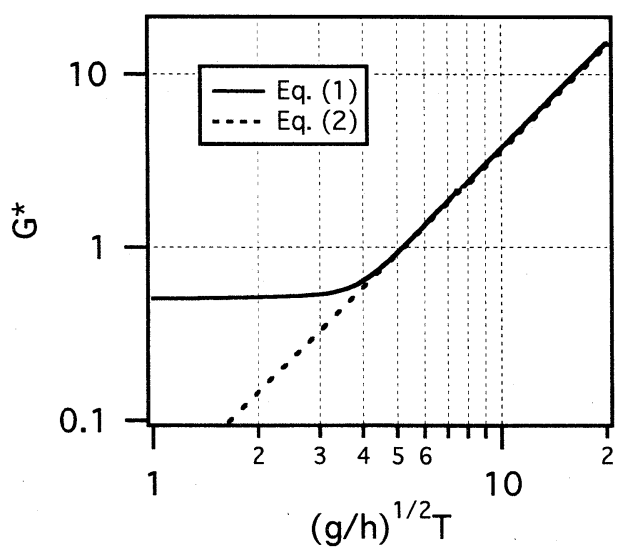

図-7 拘束波の伝達関数

\section{（4）波群性長周期波の増幅特性の比較}

次に, 日本の沿岸で観測されたいくつかのデー夕 を用いて，上記の整理法で増幅特性を比較してみ る.用いたデー夕は表 -1 に示す 4 種類である。い 
ずれも水深が比較的大きな地点での観測データであ るが, 長周期波の増幅特性を比較するには, 現象の 複雑な砕波帯内よりも沖側の方が性質をとらえやす いと考えたためである.これらのデータには，周期 の大きな気象性長周期波も含まれていることが考え られるが，ここでは特に配慮していない。図一8は 長周期波のRMS值を $H_{1 / 3} T_{1 / 3}$ に対してプロットした ものである.ただし，長周期波の有義波高として与 えられているデータは，1/4倍することによりRMS 值に変換している. 苫小牧のデー夕については, 渥 美らにより赤羽根と同一の近似式が与えられてお り, 図中に害線で示してある.これより, 平塚, 直 江津, 波崎のデータについては, $H_{1 / 3} T_{1 / 3}>10$ 範囲 ではほぼ同程度の増幅率を示しており，概ね $H_{1 / 3} T_{1 / 3}$ に線型的に変化していることがわかる. た だし，増幅率は赤羽根および苫小牧の $2 / 3$ 程度にな っている. 図中には図ー6に示した阿連（対馬）に おける近似式も破線で示してあるが，平塚での長周 期波の小さなケ一スは阿連と変動特性が似ている。

以上のように, $H_{1 / 3} T_{1 / 3}$ と長周期波のRMS值の関 係を波浪および地形条件の異なる数箇所のデータで

\begin{tabular}{|c|c|c|c|c|c|c|c|}
\hline 出 典 & 場 所 & 期間 & 海岸性状 & $\begin{array}{l}\text { 水深 } \\
(\mathrm{m})\end{array}$ & \begin{tabular}{|l|} 
砕破点 \\
付近海 \\
底勾配
\end{tabular} & $\begin{array}{c}H_{1 / 3} \\
(\mathrm{~m})\end{array}$ & $\begin{array}{c}T_{1 / 3} \\
\text { (s) }\end{array}$ \\
\hline $\begin{array}{l}\text { 藤縄 } \\
\text { 5 16) }\end{array}$ & $\begin{array}{c}\text { 相模湾奥 } \\
\text { 平塚 }\end{array}$ & $\begin{array}{c}1974 \\
\text { 台風来襲時 }\end{array}$ & $\begin{array}{c}\text { 河口近傍の } \\
\text { 砂浜海岸 }\end{array}$ & 20 & 0.03 & $0.5 \sim 3$ & $\begin{array}{l}10.5 \\
\sim 16\end{array}$ \\
\hline $\begin{array}{l}\text { 渥美 } \\
5^{17)}\end{array}$ & $\begin{array}{l}\text { 苫小牧 } \\
\text { 東港沖 }\end{array}$ & $\begin{array}{c}1992 \sim 1996 \\
\text { の長周期波 } \\
\text { 高 } 5 \mathrm{~cm} \text { 以上 } \\
\text { のケース }\end{array}$ & $\begin{array}{c}\text { 港湾近傍の } \\
\text { 砂浜海岸 }\end{array}$ & 18.5 & 0.005 & - & $5 \sim 20$ \\
\hline $\begin{array}{l}\text { 中畑 } \\
5^{18)}\end{array}$ & $\begin{array}{c}\text { 新潟直江 } \\
\text { 津港沖 }\end{array}$ & $\begin{array}{c}\text { 1999年 } \\
\text { 冬期風浪 }\end{array}$ & $\begin{array}{c}\text { 港湾近傍の } \\
\text { 砂浜海岸 }\end{array}$ & 25 & 0.015 & $\sim 5.5$ & $\begin{array}{l}5.5 \\
\sim 10.5\end{array}$ \\
\hline $\begin{array}{l}\text { 栗山 } \\
\text { 5 19) }\end{array}$ & $\begin{array}{l}\text { 茨城 } \\
\text { 波崎 }\end{array}$ & $\begin{array}{c}\text { 1997年 } \\
\text { 冬期風浪 }\end{array}$ & 砂浜海岸 & 24 & 0.01 & $\sim 5$ & $\begin{array}{l}5.5 \\
\sim 13.5\end{array}$ \\
\hline
\end{tabular}

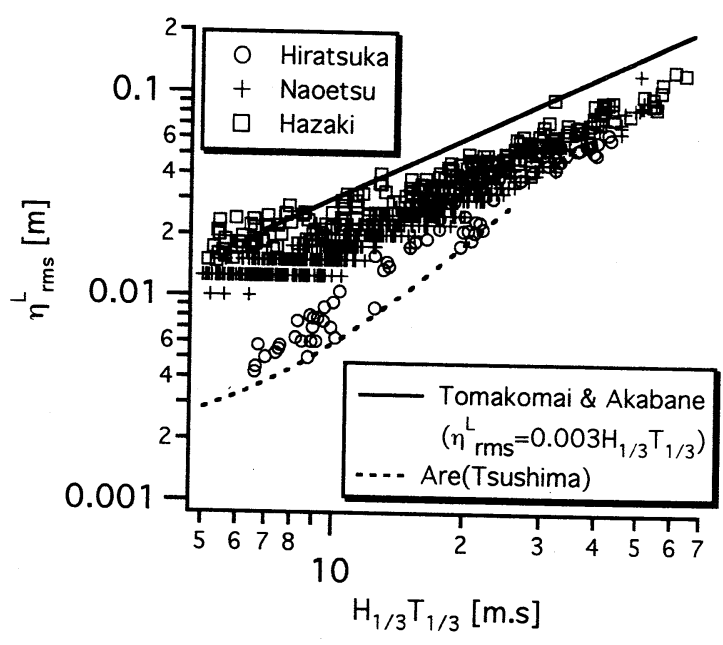

図-8 長周期波の増幅特性の比較
比較したところ，拘束波の特徵を示す対馬のデータ は他の地点に比べて長周期波が非常に小さく，増幅

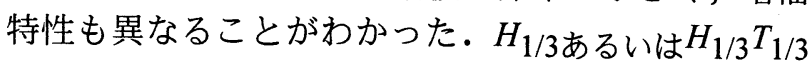
に線型な増幅特性を裏付けるデー夕は他の研究者に よっても示されている20),21)。よく用いられている 合田の予測式7)も H/hが小さい場合には波高と周期 の積に線型な表現式となっている。 Okihiro22)ら は, 数地点で得られた波浪データを用いて, 方向分 散を考慮した拘束波の計算を行って長周期波の観測

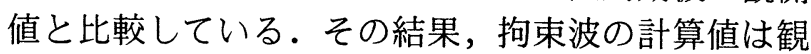
測值に比べてかなり小さくなり，観測された長周期 波の波高は有義波高と線型な関係を示すことが述べ られている。 また，Herbersら23),24)は，拘束波をバ イスペクトルを用いて求めているが, やはり観測値 は計算された拘束波よりも大きく現れており，自由 波のエネルギーが大きいと述べている．Bowers ${ }^{25)}$ は方向分散を考慮して拘束波を計算し，実測値との 差を自由波としてその増幅特性をいくつかの地点の 観測値を用いて調べている。その結果，自由波の波 高は, 有義波高に対しては $0.93 \sim 1.32$ 乗, スペクト ルピーク周期に対しては0.99〜1.59乗にそれぞれ比 例するような近似式を得ている. Herbersら24)も， 計算した拘束波を実測値から差し引くことによって 自由波を求め, その特徵を調べているが，やはり自 由波のエネルギーについては短周期波のエネルギー と線型に近い関係にあることを示している。さらに 彼らは, 自由波の大きさと地形の関係についても論 じており, 大陸棚の幅が狭い海岸や岩礁海岸では自 由波のエネルギーが小さいと述べている。

以上のような研究成果から類推すると, 長周期波 が $H_{1 / 3} T_{1 / 3}$ に線型に増幅するケースでは, 拘束波に 比べて自由波が卓越して存在していると考えられ る. 自由波の発生原因については様々な要因が考え られており, 関本8)は種々の要因について詳細に検 討している. 基本的に自由波の発生は波群の変形と 関連づけられるため, 拘束波と自由波の増幅特性は 類似していると予想されるが，砕波のような大規模 なエネルギー逸散を伴う過程で自由波が生じる場合 には，その増幅特性が拘束波と異なった性質を有す ることも考えられる. 事実, Symondsら26)によって 提案された砕破点の変動モデルを用れば，発生する 自由波は砕波波高に線型的となりうることが示され ており8),27)，また実測結果により，汀線での長周期 変動の振幅は砕波波高に比例することもわかってい る28)。これらより，砕波帯沖合で観測される自由波 は，砕破帯から沖方向に伝播してきたものと考える のが妥当であろう。したがって, Herbersら 24)が指 摘したように, 岩礁海岸では大規模な砕波が生じな いため, 自由波の発生が小さくなることが予想され る. 本論文で示したように, 阿連では波群長周期波 
成分が小さく拘束波が卓越していたのはそのためで あろう。それに対して, 苫小牧や赤羽根では広い砂 浜海岸で生じる大規模な砕波の影響で自由波のエネ ルギーが大きくなっていることが予想される。

長周期波の実測データを解析した文献の中には， 拘束波によって沿岸の長周期波が説明できるとする 論文も数多く見かける29)。著者ら 11)は，成分波の 主波向きを考慮して時系列レベルで拘束波を計算す る近似計算を提案し，赤羽根の観測デー夕について 拘束波と自由波の分離を行ったところ，実測長周期 波と拘束波の波高が同程度であっても，位相のずれ により拘束波と同程度の自由波が存在しうることを 示しており，エネルギーレベルだけの比較では自由 波の存在を見落とす可能性があることに注意する必 要があろう. 図-9は赤羽根の96年の岸沖方向流速 成分に対して拘束波と自由波を分離した例である。

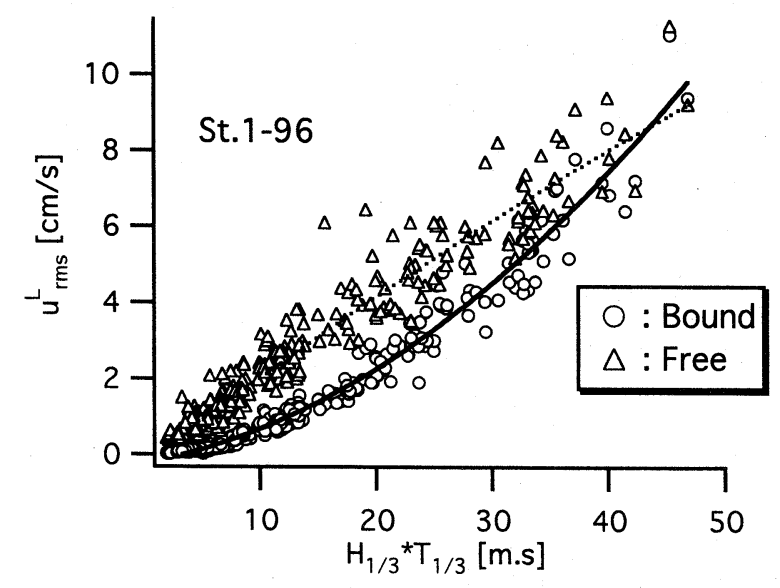

図-9 流速成分に対する拘束波と自由波の分離

\section{4. 長周期波の伝播特性}

\section{（1）波群性長周期波の伝播}

前述したように, 拘束波についてはローカルな波 条件で決まるため, 伝播特性が問題になるのは自由 波の方である。砕波帯で発生した自由波は, 沖向き あるいは沿岸方向に伝播し, 条件によっては沿岸域 にトラップされると考えられる. 図ー10は，赤羽 根における長周期波の底部流速のRMS值の経時変化 を，岸沖方向と沿岸方向に分けて示したものである が, 沿岸方向にも岸沖方向と同程度の流速成分が存 在しており，その増幅特性も類似している。 また， 岸沖および沿岸方向に離れた 2 地点の流速変動の相 関を調べたところ, いずれも高い値を示し, 岸沖お よび沿岸方向への長周期波の伝播を確認することが できた。同じ赤羽根のデータに対して，山村ら 10)は 2 地点間の相互相関を用いて，またHossain ら 30) は, 新しい入反射分離法を用いて岸沖方向に伝播す る波の特性を解析しているが, いずれも波高が大き
くなると，岸向きに拘束波が，沖向きに自由波が卓 越して伝播していることを示ている。

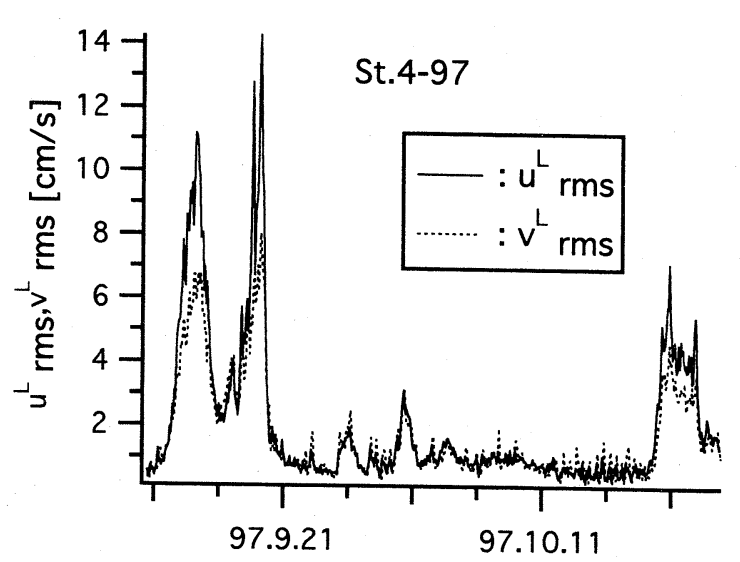

図-10 岸沖 $(u)$ および沿岸 $(v)$ 方向流速の RMS值の経時変化（赤羽根97年）

\section{（2）気象性長周期波の伝播}

3.では波群生長周期波の増幅特性のみ述べた が, 気象性長周期波については, その発生・増幅の メカニズムがまだよく分かっていない.図ー4に示 した阿連における気象性長周期波の増幅について は, 気圧デー夕と対比したところ, 低気圧が通過す る際に大きな長周期波が発生することが多いことが 分かったが, 気圧データの分解能などの問題から, 要因を特定することは難しい. 図一11は, 図ー2 に示す 3 台の波高計による水面波形の記録から求め た, 200秒以上の成分の波の時系列を示したもので あるが, 長周期の変動が港外から港内に伝播し, 伝 播とともに増幅されている様子がはっきりとらえら れている。したがって, このような気象性長周期波 は, 沿岸で発達するのではなく, 沖合で発達し沿岸 に伝播してくる性質のものであろうと推察される.

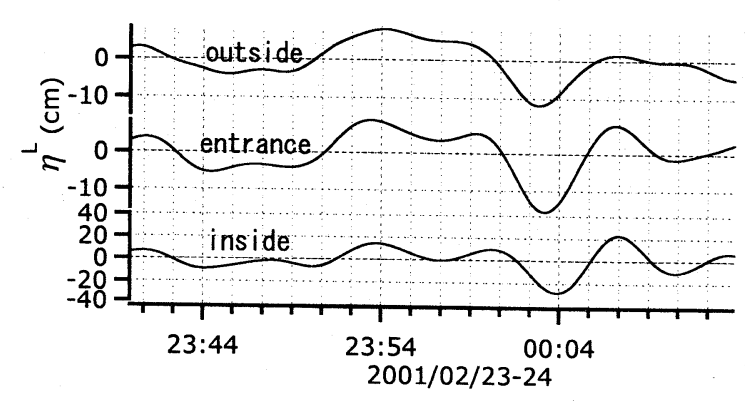

図-11 長周期波の港内への伝播の例（阿連）

\section{5.あとがき}

本論文では, 著者らが行った赤羽根および阿連で の観測デー夕を解析するとともに, 他の研究者の データの再整理と文献レビューにより, 長周期波の 
増幅特性と伝播についてその特性を論じた。異なる 論文を読む度に異なる結論に出会うといった状況 で，やや強引に議論を展開してみた。依然として不 明な点は多いが，近年精力的に行われている数多く の観測デー夕の蓄積と理論的な研究により,ぼんゃ りとではあるが, 長周期波の特性が明らかになりつ つあるといったところであろう。

謝辞：本研究を行うにあたり, 豊橋技術科学大学 院生の岡辺君にはデー夕の解析に尽力戴いた。ま た, 対馬の観測では, 大阪大学の出口教授・荒木助 手, 復建調查設計の河野・原・稲垣の諸氏, 阿連漁 協の新宮氏，および（有）アイオーテクニックの井 戸氏に大変お世話になった。ここに記して謝意を表 する.また，本論文を書くに当たり快くデータを提 供していただいた, 国土交通省港湾空港研究所の栗 山氏, 五洋建設（株）の花山氏および上越共同火力 （株）の方々に感謝するとともに，五洋建設（株） の関本氏には，論文執筆の機会を与えていただいた ことに御礼申し上げる.

\section{参考文献}

1) 山本正昭 : 銚子漁港内外の長周期波の通年観測，第 29回海講論文集, pp.198-203，1982.

2 ) 菅沼史典, 神谷昌文, 渥美洋一, 小泉信男: 現地観 測による長周期波の発生頻度と船体動摇発生予測の検 討, 海岸工学論文集, 第42巻, pp.951-955, 1995.

3 ) 田端竹千穂, 田所篤博, 平石哲也, 玉城重則: 港湾 における長周期波の増幅現象に関する現地観測, 海岸工 学論文集, 第42巻, pp.301-305, 1995.

4) 加藤一正, 柳島慎一, 栗山善昭, 磯上知良 : 荒天時 のバーム地形の侵食一長周期波に着目した現地観測一, 海岸工学論文集，第36巻，pp.354-358，1989.

5 ) 松本朗, 松岡道男, 中山哲嚴, 山本潤, 灘岡和夫, 八木宏 : 中小港湾埋没機構解明に向けての長期連続現地 観測の試み, 海岸工学論文集, 第40巻, pp.491-495, 1993.

6) 宇野木早苗 : 港湾のセイシュと長周期波について, 第 6 回海講論文集, pp.1-10, 1959.

7 ) 合田良実: 不規則波浪に伴う長周期波の諸研究につ いて, 第31回水工学に関する夏季研修会講義集, B コー ス, pp.B-6-1-20, 1995.

$8)$ 関本恒浩 : 港湾内外の長周期波の特性とその評価に 関する研究, 中央大学学位論文, 130p., 1999.

9 ) 青木伸一, 喜岡涉, 山村易見, 舟橋香, 相川久紀 : 台風の通過に伴う沿岸長周期波の増幅と伝播に関する現 地観測, 海岸工学論文集, 第44巻, pp.216-220, 1997.

10）山村易見，青木伸一: 外洋に面した小規模港湾内外 における長周期波の挙動, 海岸工学論文集, 第 45 巻, pp.311-315, 1998.

11）山村易見，青木伸一，舟橋香 : 入射波の方向分散を 考慮した拘束長周期波の推定と自由長周期波の伝播特 性, 海岸工学論文集, 第46巻, pp.286-290, 1999.

12) Yoshida, K.: On the ocean wave spectrum, with special reference to the beat phenomena and the "1-3 minute waves" , J. Oceanogr. Soc. Japan, Vol.6, No.2, pp.49-56, 1950.

13) Longuet-Higgins, M. S. and R. W. Stewart: Radiation stress and mass transport in gravity waves, with application to surf beat, J. Fluid Mech., Vol.13, pp.481-540, 1962.

14) Ottesen-Hansen, N. E., S. E. Sand, H. Lundgren, T. Sorensen and H. Gravesen: Correct reproduction of groupinducedlong waves, Proc. 17th ICCE, pp.784-800, 1980.

15) Sand, S. E.: Long waves in directional seas, Coastal Engineering, Vol.6, No.3, pp.195-208, 1982.

16）藤縄幸雄，岡田憲司，渡部勲：波浪に伴う長周期波 の特性(I), 国際防災科学技術センタ一研究報告, 第 15 号, pp.159-191, 1976.

17）渥美洋一, 和歌山義樹, 國田淳, 関口信一郎，川口 勉，平石哲也，青木伸一，上田茂 : 長周期波の港内侵入 過程の現地観測と長周期波高予測式の検討，海岸工学論 文集，第44巻，pp.221-225，1997.

18）中畑禎, 落合敏浩, 柏原裕彦, 花山格章, 森屋陽 一, 関本恒浩 : 冬期日本海の現地観測に基づく浅海域へ の入射長周期波の評価, 海岸工学論文集, 第 48 巻, pp. 256 $-260,2001$.

19）栗山善昭, 山田貴裕, 西守男雄 : 沿岸砂州と長周期 波との相互作用に関する現地観測, 海岸工学論文集, 第 48巻, pp.156-160, 2001.

20）笠井雅広, 佐藤慎司: 台風に伴う波浪と長周期変 動, 海岸工学論文集, 第46巻, pp.301-305, 1999.

21）堀沢真人, 佐藤典之, 大中晋, 青野利夫, Eric C. Cruz, 早川淳 : 港内外長周期波の現地観測とその予測手 法, 海岸工学論文集, 第45巻, pp.301-305, 1998.

22) Okihiro, M., R. T. Guza and R. J. Seymour: Bound infragravity waves, J. Geophys. Res., Vol.97, No.C7, pp.11.453 -11.469, 1992.

23) Herbers, T. H. C., S. Elgar and R. T. Guza: InfragravityFrequency (0.005-0.05) Motions on the shelf. Part I: Forced waves, J. Physical Oceanogr., Vol.24, pp.917-927, 1994.

24) Herbers, T. H. C., S. Elgar R. T. Guza, and C. O' Reilly: Infragravity-Frequency (0.005-0.05) Motions on the shelf. Part II: Free waves, J. Physical Oceanogr., Vol.25, pp.1063-1079, 1994.

25) Bowers, E. C.: Low frequency waves in intermediate water depth, Proc. 23rd ICCE, pp.832-845, 1992.

26) Symonds, G., D. A. Huntley and A. J. Bowen: Twodimensional surf beat: long wave generation by a time-varying breakpoint, J. Geophys. Res., Vol.87, No.C1, pp.492-498, 1982. 27) Mizuguchi, M.: A simple analysis of long wave generation by time-varying breakpoint, Coastal Engineering in Japan, Vol.38, No.2, pp.105-110, 1995.

28) Huntley, D. A., M. Davidson, P. Russell, Y. Foote and J. Hardisty: Long waves and sediment movement on beaches: Recent observations and implications for modelling, J. Coastal Res., Vol.15, pp.215-229, 1993.

29）永井紀彦, 橋本典明, 清水勝義, 平井宣典, 伊藤一 教, 東江隆夫 : 長期連続観測による沖合長周期波の変動 特性, 海岸工学論文集, 第43巻, pp.216-220, 1996.

30) Hossain, A.，北野利一，喜岡渉：沖浜における長周期 波の挙動, 海岸工学論文集, 第48巻, pp.271-275, 2001. 